\title{
Urea kinetics in neonates receiving total parenteral nutrition
}

\author{
R A Wheeler, D M Griffiths, A A Jackson
}

\begin{abstract}
Urea kinetics were measured on 10 occasions in eight neonates who had not received an oral intake from birth and were maintained on total parenteral nutrition. After a prime/intermittent oral dose of ${ }^{15} \mathrm{~N}^{15} \mathrm{~N}$-urea over 14 hours urine was collected every three to four hours, urea isolated, and kinetics determined from the plateau level of enrichment in urea, measured by isotope ratio mass spectrometry. The total parenteral nutrition provided $393 \mathrm{~kJ}(94 \mathrm{kcal}) / \mathrm{kg} / \mathrm{day}$ and $360 \mathrm{mg}$ nitrogen/kg/day. Urea production was mean (SD) 84 (44) mg nitrogen/ $\mathrm{kg} / \mathrm{day}$, or $50 \%$ of intake. Urinary excretion of urea, 39 (16) $\mathrm{mg}$ nitrogen/kg/day, was $40 \%$ of production. Therefore $54 \%$ of urea production was salvaged through the lower bowel, 45 (35) $\mathrm{mg}$ nitrogen $/ \mathrm{kg} / \mathrm{day}$. It is concluded that even in infants who have never had a regular dietary intake the microflora of the lower bowel is sufficiently developed to salvage urea nitrogen for further metabolic interaction, however it is not clear whether the rate of salvage is adequate to satisfy the metabolic demand.

(Arch Dis Child 1993; 69: 24-27)
\end{abstract}

We have established that in children and adults the process whereby urea nitrogen is salvaged in the lower bowel through the metabolic activity of the colonic microflora plays a central part in the process of accommodation by the body to variations in protein intake. ${ }^{1-3}$ The normal diet for the newborn is breast milk and urea comprises a significant proportion (about $15 \%$ ) of the nitrogen in breast milk. ${ }^{4}$ During the first year of life there may be significant retention of an oral dose of ${ }^{15} \mathrm{~N}$-labelled urea demonstrating the presence of a functional salvage system. ${ }^{56}$ In an earlier study we were able to quantify the intensity of salvage in a series of neonates who were recovering from gastrointestinal surgery and found that $80 \%$ of the urea produced in the body was salvaged. ${ }^{7}$ In this situation the salvaged urea nitrogen was $54 \%$ of the dietary intake and therefore made a significant contribution to the 'effective dietary intake' and the achievement of a positive nitrogen balance. ${ }^{3}$

The control of the process through which urea nitrogen is salvaged is not clear, but is directly associated with the metabolic activity of the colonic microflora. ${ }^{8}$ In the past we had assumed that the influence exerted by the dietary intake upon the microflora would be direct, through the availability of dietary residue as a potential source of energy and other nutrients. However, we found that in adults with no dietary intake who were being maintained on total parenteral nutrition during the convalescent period, the salvage of urea nitrogen was enhanced. ${ }^{9}$ In subjects on antibiotic treatment the magnitude of the salvage was significantly reduced, although not abolished completely, implicating the colonic microflora in the response. The impression that the ability to salvage urea plays a critical part in the ability of the body to cope with a limited availability of dietary protein was reinforced by the observation that in adults the salvage system fails as nitrogen balance becomes negative. ${ }^{3}$ We were interested to explore the pattern of urea salvage in neonates who had never had an oral intake of food and were being maintained on total parenteral nutrition in the postoperative period. Under these conditions the demand for protein would be very high through a combination of the requirements for recovery during convalescence and the normal demands for growth. Yet, at the same time, an integral part of the mechanism whereby the body usually accommodates to increased demands, the urea salvage system, would not have been expected to develop to functional competence because the normal resident colonic flora would not have had the opportunity to become established in the absence of a normal dietary intake.

\section{Subjects and methods} SUBJECTS

Ten studies were carried out in eight infants in the neonatal period. All but one of the infants had operative procedures and all had been receiving exclusively total parenteral nutrition. Two infants were studied on two occasions, one week apart. At the time of study each infant was at least seven days' postoperative and none had received antibiotics for at least seven days. All were breathing room air at the time of study and none had identifiable sepsis, enteric or renal pathology. The diagnoses of the infants and the operative interventions are shown in table 1 . Seven infants had abdominal wall defects as the primary diagnosis and primary operative closure was performed in five. Two had a staged closure using a Silastic silo and, incidentally, one also had choanal atresia. One infant with a left sided chylothorax was treated non-operatively with an intercostal tube drain. The study had the approval of the Southampton Hospitals and South West Hampshire Health Authority ethics subcommittee. The parents of the infants gave consent for the study, without prejudice. 
Table 1 The clinical characteristics of the subjects in the study

\begin{tabular}{|c|c|c|c|c|c|c|c|}
\hline \multirow{2}{*}{$\begin{array}{l}\text { Infant } \\
\text { No }\end{array}$} & \multirow[b]{2}{*}{$\operatorname{Sex}$} & \multirow{2}{*}{$\begin{array}{l}\text { Gestation } \\
\text { (weeks) }\end{array}$} & \multirow{2}{*}{$\begin{array}{l}\text { Birth } \\
\text { weight } \\
\text { (g) }\end{array}$} & \multirow{2}{*}{$\begin{array}{l}\text { Postnatal } \\
\text { age } \\
\text { (weeks) }\end{array}$} & \multicolumn{2}{|l|}{ Days since } & \multirow[b]{2}{*}{ Diagnosis/operation } \\
\hline & & & & & Operation & Antibiotics & \\
\hline $\begin{array}{r}1 \mathrm{~A} \\
\mathrm{~B}\end{array}$ & $\mathbf{F}$ & 35 & 1650 & $\begin{array}{l}2 \\
3\end{array}$ & $\begin{array}{l}14 \\
19\end{array}$ & $\begin{array}{l}13 \\
18\end{array}$ & Gastroschisis, silo repair \\
\hline 2 & $\mathbf{M}$ & 36 & 1880 & 2 & 12 & 12 & Gastroschisis, primary closure \\
\hline 3 & $\mathbf{M}$ & 37 & 2900 & 3 & 18 & 17 & Gastroschisis, primary closure, choanal atresia \\
\hline $\begin{array}{c}4 \mathrm{~A} \\
\mathrm{~B}\end{array}$ & $\mathbf{M}$ & 37 & 2900 & $\begin{array}{l}1 \\
2\end{array}$ & $\begin{array}{r}9 \\
15\end{array}$ & $\begin{array}{r}8 \\
14\end{array}$ & Gastroschisis, primary closure \\
\hline 5 & $\mathbf{M}$ & 38 & 4100 & 2 & 13 & 12 & Gastroschisis, silo repair \\
\hline 6 & $\mathrm{~F}$ & 39 & 3400 & $\overline{1}$ & 11 & 10 & Exomphalos major, primary closure \\
\hline 7 & $\mathrm{~F}$ & 40 & 3800 & 3 & & 20 & Chylothorax \\
\hline 8 & $\mathrm{~F}$ & 41 & 3100 & 1 & 9 & 9 & Exomphalos major, primary closure \\
\hline
\end{tabular}

\section{STUDY DESIGN}

All infants received total parenteral nutrition at $100 \mathrm{ml} / \mathrm{kg} /$ day to provide a total energy intake of $16.3 \mathrm{~kJ} / \mathrm{kg} /$ hour $(3.9 \mathrm{kcal} / \mathrm{kg} /$ hour, $94 \mathrm{kcal} / \mathrm{kg} /$ day) and $15 \mathrm{mg}$ nitrogen $/ \mathrm{kg} /$ hour $(2.2 \mathrm{~g}$ protein $/ \mathrm{kg} /$ day $)$. Urea kinetics were measured using prime/continuous intragastric doses of $\left[{ }^{15} \mathrm{~N}^{15} \mathrm{~N}\right]$ urea $(97 \cdot 7$ atoms percent, MSD Isotopes) through a nasogastric tube. An earlier study had determined the appropriate prime and the time scale for the achievement of a steady isotopic state in urinary urea. ${ }^{7} A$ bolus dose of $\left[{ }^{15} \mathrm{~N}^{15} \mathrm{~N}\right]$ urea, equivalent to 10 hours of infusion was given at the start of the study to shorten the time taken to reach isotopic plateau in urine. After four hours, this was followed by the continuous intragastric infusion of isotope at 0.0625 $\mathrm{mg} / \mathrm{kg} /$ hour for 14 hours. A baseline urine was collected before the administration of any isotope for the measurement of natural abundance. After the administration of the bolus dose urine was collected from six hours until 18 hours at three to four hourly intervals. Urine was collected by continuous aspiration and air insufflation of a polythene bag, which was custom made to fit over the penile shaft or the vulva. ${ }^{1011}$ Maintaining a continent system for the necessary period was more difficult in females and only four studies were completed in girls. Both reduced and positive pressure were achieved with a single pump (Dymax 2 electrical pump, Charles Austen Pump). The aspiration circuit included a flask for the collection of urine and the prevention of liquid returning to the pump itself. The flask was chilled in an ice bucket to minimise ureolysis before removal of the sample every three hours. Urine samples were measured and stored frozen in acidified containers.

\section{ANALYSES}

The concentration of urea and ammonia in urine was measured by using the Berthelot method, ${ }^{12}$ and urea nitrogen was isolated from urine for mass spectrometry by short ion exchange chromatography. ${ }^{13}$ Nitrogen gas was liberated from urea by reaction with alkaline hypobromite. In this reaction nitrogen is released from urea in a monomolecular reaction, ${ }^{14}$ hence the relative proportions of $\left[{ }^{15} \mathrm{~N}^{15} \mathrm{~N}\right]$ urea, $\left[{ }^{15} \mathrm{~N}^{14} \mathrm{~N}\right]$ urea, and $\left[{ }^{14} \mathrm{~N}^{14} \mathrm{~N}\right]$ urea can be determined. Measurements were carried out in a triple collector (SIRA 10; VG Isogas) isotope ratio mass spectrometer.

\section{CALCULATIONS}

Urea kinetics were calculated by using the model of Jackson et al. ${ }^{15}$ Ingested protein is made available to metabolism as amino acids, which mix with the general body pool; amino acids also derive from protein degradation. Once an isotopic steady state has been achieved, the dilution of the infused $\left[{ }^{15} \mathrm{~N}^{15} \mathrm{~N}\right]$ urea gives a measure of the rate of urea production in the body. A proportion of this urea is excreted in the urine. The difference between the urea produced and that excreted is presumed to have been hydrolysed in the bowel with the nitrogen being salvaged and returned to the general metabolic pool. A part of the salvaged nitrogen is resynthesised to urea, with the remainder being available and utilised for the synthesis of amino acids and proteins. The total urea produced comprises a component derived from the catabolism of dietary and endogenous amino acids and a component derived from urea hydrolysis in the bowel. The urea entering the bowel is doubly labelled $\left[{ }^{15} \mathrm{~N}^{15} \mathrm{~N}\right]$ urea. The recycled urea that is synthesised in the liver from ${ }^{15} \mathrm{NH}_{3}$, generated from urea hydrolysed in the bowel, will be singly labelled $\left[{ }^{15} \mathrm{~N}^{14} \mathrm{~N}\right]$ urea. The urea nitrogen which is recycled to urea synthesis is determined from measurements of singly labelled urea in the urine. Details and calculations are given by Jackson et al. ${ }^{15}$

\section{Results}

The infants were delivered on average after 37.5 weeks' gestation (range 35 to 41 weeks) and weighed $2840 \mathrm{~g}$ (range 1650-4100) at birth (table 1). At the time of study they were 1 to 3 weeks old. One infant had been jaundiced at birth, but at the time of study serum bilirubin concentration was within the normal range, as were other standard biochemical values. Ten studies were completed satisfactorily. Plateau enrichments in urinary urea were obtained for $\left[{ }^{15} \mathrm{~N}^{15} \mathrm{~N}\right]$ urea and $\left[{ }^{15} \mathrm{~N}^{14} \mathrm{~N}\right]$ urea. The average coefficient of variation in enrichment at plateau for $\left[{ }^{15} \mathrm{~N}^{15} \mathrm{~N}\right]$ urea was $5 \%$ (range $1-10 \%$ ), whereas for $\left[{ }^{15} \mathrm{~N}^{14} \mathrm{~N}\right]$ urea it was $18 \%$ (range $4-36 \%$ ). The comparatively high variation in the plateau for $\left[{ }^{15} \mathrm{~N}^{14} \mathrm{~N}\right]$ urea is a reflection of the relatively low level of enrichment for this species, such that small absolute differences appear disproportionately large.

The absolute and relative values for urea kinetics for the individual infants are given in table 2. The dietary intake was $360 \mathrm{mg}$ 
Table 2 Measures of urea kinetics in a group of neonates on total parenteral nutrition. All values are given as $\mathrm{mg}$ nitrogen $/ \mathrm{kg} /$ day; nitrogen intake was $360 \mathrm{mg}$ nitrogen/kg/day

\begin{tabular}{lccccc}
\hline $\begin{array}{l}\text { Infant } \\
\text { No }\end{array}$ & Production & Excretion & Salvage & Recycled & Utilised \\
\hline 1A & 54 & 54 & 0 & 0 & 0 \\
B & 181 & 54 & 128 & 54 & 74 \\
2 & 114 & 50 & 64 & 7 & 75 \\
3 & 114 & 54 & 60 & 7 & 54 \\
4A & 57 & 30 & 27 & 0 & 27 \\
B & 54 & 30 & 24 & 3 & 20 \\
5 & 40 & 7 & 34 & 0 & 34 \\
6 & 74 & 27 & 47 & 3 & 44 \\
7 & 54 & 37 & 17 & 0 & 17 \\
8 & 101 & 47 & 54 & 0 & 54 \\
Mean & 84 & 39 & 45 & 7 & 38 \\
SD & 44 & 16 & 35 & 17 & 22 \\
\hline
\end{tabular}

nitrogen $/ \mathrm{kg} /$ day $(2 \cdot 2 \mathrm{~g}$ protein $/ \mathrm{kg} /$ day $)$ and urea production was mean (SD) 84 (44) $\mathrm{mg}$ nitrogen $/ \mathrm{kg} /$ day. Urinary urea excretion was 39 (16) $\mathrm{mg}$ nitrogen/ $\mathrm{kg} /$ day. Hence, the salvage of urea nitrogen was 45 (35) $\mathrm{mg}$ nitrogen $/ \mathrm{kg} /$ day, of which $7 \mathrm{mg}$ nitrogen $/ \mathrm{kg} /$ day returned to urea production while $38 \mathrm{mg}$ nitrogen $/ \mathrm{kg} /$ day was available for amino acid formation. Therefore on average urea production was $23 \%$ of the nitrogen intake, whereas urea nitrogen excretion was $11 \%$ of the nitrogen intake, indicative of a significantly positive nitrogen balance. About $46 \%$ of the urea produced was excreted in the urine and $54 \%$ was salvaged for further metabolic interaction.

There was no obvious relationship between any component of urea kinetics and the gestation age, birth weight, or postnatal age for this group of infants.

\section{Discussion}

In the present study the rates of urea synthesis, excretion, and salvage have been measured in newborn infants who were maintained on total parenteral nutrition and had never had a normal oral intake. Inevitably the infants represent a group requiring special care, and all but one had surgical intervention. At the time of study of all infants had recovered from the acute operative experience, their intake of energy and protein was adequate to support growth, and they were in positive apparent nitrogen balance. The measurements of urea kinetics show that only half of the urea produced was excreted in the urine with the other half being salvaged and available for metabolic use. These results imply that despite no oral intake the infants had a gastrointestinal

Table 3 The values for urea kinetics obtained in neonates on total parenteral nutrition in the present study are compared with those obtained in a previous study for neonates on an oral intake of formula

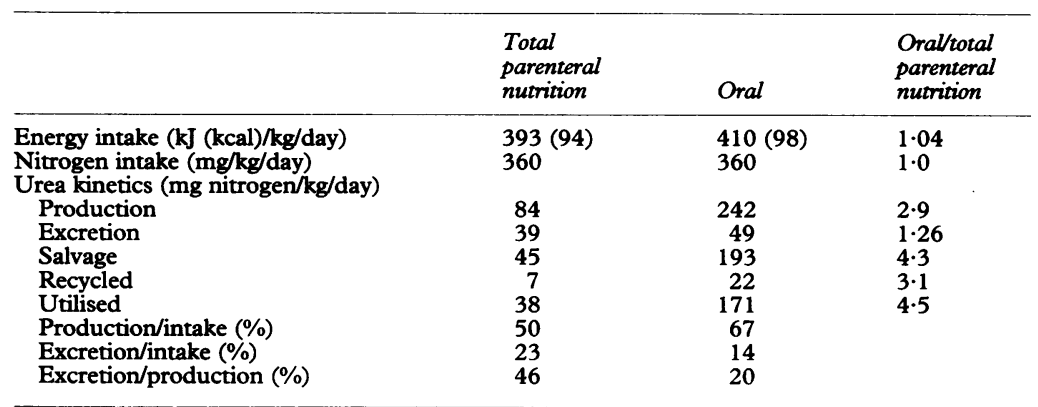

flora that was metabolically functional and capable of interacting with the host's metabolism.

Studies of this kind are difficult to carry out for a number of reasons. The subjects were carefully selected so that at the time of study they were in a stable metabolic state and required no special therapeutic support other than total parenteral nutrition. The complete collection of urine over a period of time required close attention to detail especially in girls and practice was needed before the collections were complete and satisfactory. The method presumes that the dose of isotope given by nasogastric tube is absorbed intact without being hydrolysed. It has been shown in adults that the extent to which hydrolysis of the dose has taken place before absorption can be assessed by the result obtained for the apparent recycling of urea nitrogen to urea synthesis. Under circumstances where the dose is hydrolysed before absorption this value is inappropriately high. ${ }^{16}$ For all the studies in the present series this value was low, except for subject 2 , and hence the results of this study might be suspect. With this exception all the other studies were considered to be technically satisfactory.

The recovery in urine of intravenously administered $\left[{ }^{15} \mathrm{~N}^{15} \mathrm{~N}\right]$ urea has been measured in adults suffering from intestinal failure ${ }^{9}$ and rates of urea kinetics derived. ${ }^{17}$ Under these circumstances it was found that the rate of urea salvage was about $44 \%$ of urea production, similar to the findings of the present study. A number of authors have given a single dose of labelled urea to infants and measured the recovery of isotope in the urine, values for recovery varied over a wide range under uncontrolled conditions, from $10 \%$ to $80 \% .^{56}$ In none of these studies have the data been used to derive values for urea production and salvaging.

In table 3 a comparison is given for the rates of urea kinetics measured in an earlier study for a group of infants convalescing postoperatively, who were receiving an oral feed. ${ }^{7}$ These infants were receiving $360 \mathrm{mg}$ nitrogen $/ \mathrm{kg} /$ day orally and had a rate of urea production of $242 \mathrm{mg}$ nitrogen $/ \mathrm{kg} / \mathrm{day}, 80 \%$ of which was salvaged with only $20 \%$ being excreted in the urine. The only other comparative data for infants of this age have been reported by Kalhan and Gilfillan, ${ }^{18}$ who found that normal infants produced 294 and infants of diabetic mothers $341 \mathrm{mg}$ urea/kg/day (137 and $160 \mathrm{mg}$ nitrogen/kg/day). We know from studies in older infants that all aspects of urea kinetics can be affected by the intake of both energy and nitrogen relative to the metabolic demand. ${ }^{1}$ Therefore without more detailed information on the metabolic state of the infants it is difficult to put the findings of Kalhan and Gilfillan $^{18}$ into context. Nevertheless, from the data reported here and that of others, it is clear that the salvaging of urea nitrogen is an active process in the newborn period. Even in the absence of an adequate dietary intake the colonisation of the bowel is able to support a flora which is active in this respect. 
As in the older infant and adult, the process of urea nitrogen salvage appears to be responsive to the intake of nutrients and the metabolic demand of the host from a very early age. The microflora of the colon might be seen as actively participating in metabolism and there is need to consider with care how surgical or other therapeutic interventions that are likely to disturb this system might influence overall metabolism. ${ }^{19}$ In adults the inability to salvage urea nitrogen effectively can be associated with an inability to maintain adequate nitrogen balance. ${ }^{3}$ There has been the tendency to play down the functional significance of the salvage mechanism on the assumption that the nitrogen coming from hydrolysed urea is unlikely to be of great metabolic significance on the presumption that it can only be used for the formation of the non-essential amino acids. ${ }^{20}$ The large amounts of nitrogen moving through the salvage pathway together with the data which suggest that the bacterial synthesis of essential as well as non-essential amino acids from urea nitrogen might be available to the host in functionally significant amounts ${ }^{21}$ suggest that this opinion will have to be reevaluated. If the amino acids synthesised by bacteria were available to the host, the practical implications of any limitation in the salvage of urea nitrogen would have to be considered. In adults on total parenteral nutrition the salvage of urea nitrogen was enhanced. ${ }^{9} 17$ Therefore, although the neonates on total parenteral nutrition were able to salvage urea, it might have been expected that they would salvage more urea than neonates fed orally. The finding that the rate at which urea nitrogen was salvaged was only one quarter of that seen in neonates fed enterally may be of metabolic significance.

This work was supported in part by The Rank Foundation, The Rank Prize Funds, The Hedley Foundation, and the Wessex Medical Trust.

1 Jackson AA, Doherty J, deBenoist M-H, Hibbert J, Persaud C. The effect of the level of dietary protein, carbohydrate and fat on urea kinetics in young children during rapid catch-up weight gain. Brf Nutr 1990; 64: 371-85.

2 Langran M, Moran BJ, Murphy JL, Jackson AA. Adaptation to a diet low in protein: effect of complex carbohydrate upon urea kinetics in normal man. Clin Sci 1992; 82: 191-8.

3 Danielsen M, Jackson AA. Limits of adaptation to a diet low in protein in norman man: urea kinetics. Clin Sci 1992; 83: $103-8$.

4 Harzer G, Franzke V, Bindels JG. Human milk nonprotein nitrogen components: changing pattern of free amino acids and urea in the course of early lactation. $\mathrm{Am} \mathcal{f}$ Clin acids and urea in the cour

5 Heine $\mathrm{W}$, Tiess $\mathrm{M}$, Wutzke $\mathrm{KD} .15 \mathrm{~N}$ tracer investigations of the physiological availability of urea nitrogen in mothers milk. Acta Paediatr Scand 1986; 75: 439-43.

6 Fomon SJ, Matthews DE, Bier DM, et al. Bioavailability of dietary urea nitrogen in the breast-fed infant. 7 Pediatr 1988; 113: 515-7.

7 Wheeler RA, Jackson AA, Griffiths DM. Urea production and recycling in neonates. F Pediatr Surg 1991; 26: and recyc

8 Levenson SM, Crowley LV, Horowitz RE, Malm OJ. The metabolism of carbon labelled urea in the germ free rat. metabolism of carbon labelled

9 Moran BJ, Karran SJ, Jackson AA. Enhanced retention of urea nitrogen in patients on total parenteral nutrition for intestinal failure. Clinical Nutrition 1991; 10: 67-70.

$10 \mathrm{Liu} \mathrm{HY,} \mathrm{Anderson} \mathrm{GJ.} \mathrm{A} \mathrm{method} \mathrm{for} \mathrm{long} \mathrm{term} \mathrm{quantitative}$ and fractional urine collection. $\mathcal{F}$ Pediatr 1967; 70: 276-9.

11 Dauncey MJ, Shaw JCL, Urman J. The absorption and retention of magnesium, zinc and copper by low birth weight infants fed pasteurised human breast milk. Pediatr Res 1977; 11: $991-4$.

12 Kaplan A. Urea nitrogen and ammonia nitrogen. In: Meites S, ed. Standard methods in clinical chemistry. Vol 5 . New York: Academic Press, 1965: 245-56.

13 Jackson AA, Golden MHN, Jahoor PF, Landman JP. The isolation of urea nitrogen and ammonia nitrogen from biological samples for mass spectrometry. Anal Biochem 1980; 105: 14-7.

14 Walser M, George J, Bodenlos LJ. Altered proportions of isotopes of molecular nitrogen as evidence of a monomolecular reaction. Fournal of Chemical Physiology 1954; 22: 1146 .

15 Jackson AA, Picou D, Landman J. The non-invasive measurement of urea kinetics in normal man by a constant
infusion of ${ }^{15} \mathrm{~N}^{15} \mathrm{~N}$-urea. Human Nutrition: Clinical infusion of ${ }^{15} \mathrm{~N}^{15} \mathrm{~N}$-urea.

16 Hibbert JM, Forrester T, Jackson AA. Urea kinetics: comparison of oral and intravenous dose regimes. Eur $f$ Clin Nutr 1992; 46: 405-9.

17 Jackson AA, Moran BM. Urea kinetics and total parentera nutrition. Am f Clin Nutr 1992; 55: 481.

18 Kalhan SC, Gilfillan CA. Intrauterine nutrition and the newborn. In: Jones CT, Nathanielsz PW, eds. The physiological development of the fetus and newborn. London: Academic Press, 1985: 739-46.

19 Moran BJ, Jackson AA. Function of the human colon. $\mathrm{Br} \mathcal{F}$ Surg 1992; 79: 1132-7.

20 FAO/WHO/UNU. Energy and protein requirements. Report of an expert consultation. Technical Report Series 724. Geneva: World Health Organisation, 1985

21 Tanaka N, Kubo K, Shiraki K, Koishi H, Yoshimura H. A pilot study on protein metabolism in Papua New Guinea highlanders. F Nutr Sci Vitaminol (Tokyo) 1980; 26: 247-59. 